\title{
Improving Problem-Solving AbILITY ANd CHARACTER IN SUBJECT- SPECIFIC PEdagogic With HeURistic Strategy
}

\author{
Yudi Darma ${ }^{1)}$, Dede Suratman ${ }^{2)}$, Ahmad Yani T. ${ }^{3)}$, Utin Desy Susiaty ${ }^{4)}$ \\ ${ }^{1)}$ IKIP PGRI Pontianak, Pontianak, Indonesia \\ E-mail: yudidarma@ikippgriptk.ac.id \\ ${ }^{2)}$ Universitas Tanjungpura, Pontianak, Indonesia \\ E-mail:d_suratman@yahoo.com \\ ${ }^{3)}$ Universitas Tanjungpura, Pontianak, Indonesia \\ E-mail: ahmadyani@gmail.com \\ ${ }^{4)}$ IKIP PGRI Pontianak, Pontianak, Indonesia \\ E-mail:d3or4f4ty4@gmail.com
}

\begin{abstract}
This study aimed mainly at producing Subject Specific Pedagogic (SSP) Statistics based on Character-filled Heuristic Strategies to Improve Students' Qualified Problem-Solving Ability built on the level of validity, practicality, and effectiveness. The study at this time was in synergy with the previous research as a new frame of mind that became the concept of development in achieving the main objectives. The present study employed a quantitative descriptive method with logical, analytical, and descriptive reasonings supported with relevant literature data. The instruments used were a test of problem-solving abilities and a questionnaire that was then analyzed descriptively and inferentially with two-way ANOVA formula. The study concluded that the heuristic strategy through the stages of identification, plan, do and check is an alternative solution to learning mathematics with high strengths and potentials in integrating characters into learning scenarios to be able to improve students' problem-solving skills and develop their character containing Subject-Specific Pedagogic.
\end{abstract}

Keywords: Subject Specific Pedagogic; Heuristic Strategy; Character; Problem Solving Ability

\section{INTRODUCTION}

The sequence of learning starts with planning and implementing to evaluating learning. Achievement of competence is the starting point (goal) in each learning, and the success of learning is strongly influenced by the maturity of preparation, implementation and evaluation inseparable from important roles of and determined by the learning tools (Superfine, 2008; Kilpatrick, Swafford, and Findell, 2001).

The problem with learning tools is not only in their limited availability and their suitability with the needs in the field but also in their uninternalized with character education. Although character education is one of the national goals developed in every level of education with the hope of forming an intelligent, good and strong character generation, the character content must be included as an integral part of education starting from the planning of learning and implementation to evaluation.

The nature of education is to humanize humans which is very potential to do during the learning process since the learning process is an activity in direct contact with students (Shadiq, 2009). Accordingly, it requires learning tools that must be developed not only to improve academic competence alone but also to direct student character development activities.

Character education is one involving aspects of knowledge (cognitive), feeling (affective), and action (psychomotor). The purpose of holding character education is to create a complete Indonesian human being who is faithful and devoted to God Almighty, has a noble character and has a high responsibility in carrying out life as stated in the Nawacita items launched by the President through the National Movement for Mental Revolution (GNRM) to 
strengthen the character of the nation, and "towards Indonesia Gold Generation in 2045" (Rokhman, et al., 2014).

Besides, with an emphasis on affective aspects, several studies have identified that most students have disadvantages in supporting the progress of teaching and learning mathematics and in doing problem-solving. Such a shown attitude brings a negative influence on students' awareness to engage in problem-solving activities. When dealing with math problems, their problem-solving abilities have not been the main activity in solving problems, and have not been used as a way to evaluate their failure or success in solving mathematical problems (Corte et al, Lester et al, Schoenfeld in Darma and Firdaus, 2016: 2).

Most students still experience difficulties in using various forms of problem-solving abilities (e.g. Boonen, et al, 2013; Verschaffel et al., 1999) to explain mathematical ideas and solve mathematical problems. This condition certainly needs to be handled, considering that each student must complete a thesis to obtain a bachelor's degree and this requires statistical skills to analyze the results of his or her research. Besides, they are mathematics teacher candidates who are required not only to develop problem-solving skills of their students but also be able to demonstrate good character as moral guidance, since 'learning mathematics is also seen as a social activity that requires understanding and uses of mathematical strategies'(Ginsburg, et al., 2015; Schoenfeld, 1992; Sfard, 2012).

Choosing the right learning strategy will support the development of these problem-solving abilities (Ulger, Yiğittir, Ercan, 2014). A heuristic problem-solving strategy is one alternative mathematics learning strategy that is considered the potential to improve students' problemsolving abilities (Chavez, 2007; Hoon, 2013). Strategies with this approach consider the capabilities to be developed and directs students to mathematical problem-solving skills (Koichu, Berman, and Moore, 2014; Kusdinar, 2016).

The integration of character education into mathematics learning equips students with the logical, creative, systematic thinking ability and the cooperative ability (Kemdiknas, 2010). Mathematics learning is seen as a medium for student character education. Common problemsolving steps, as developed by Polya (Schoenfeld, 1980; Reys et.al., 1998; Suherman, 2001) which include understanding the problem, planning a solution, solving the problem according to plan, and re-checking as a heuristic strategy, is a rational and ideal step in internalizing character values.

Government Regulation Number 19 of 2005 (PP No. 12 tahun 2005) concerning National Education Standards, Article 20 states that the planning of the learning process includes syllabus and learning implementation plans (lesson plan) that contain at least learning objectives, teaching materials, teaching methods, learning resources, and assessment of learning outcomes. Aligned to this regulation, one effort to improve the quality of the learning process in the classroom is by developing an ideal learning tool in the planning of "learning processes that can be packaged in the Subject Specific Pedagogic (SSP)" (Bacher, 1991).
The development of separate learning planning will lead to the not optimal achievement of learning objectives. With this notion, the development of subject-specific pedagogic in statistical courses is required so that there is harmony among the steps of learning, the students' worksheets, their reading materials (textbooks), and assessment instruments that all go through heuristic strategies with character education. Besides complementing the appropriateness of previous research that only emphasizes teacher competency (Ulger, Yiğittir, Ercan, 2014), the present study emphasizes the provision of SSP which is an integral and inseparable practice of developing hard skills and soft skills in mathematics learning.

The results of the research by Darma and Firdaus (2016), showed that mathematical problem-solving abilities in terms of student creativity through metacognitive learning were better than through conventional learning, and "heuristic strategies with metacognitive approaches were able to improve mathematical problem-solving skills in terms of creativity and independence of student learning".

Enhancing mathematical problem-solving abilities is of great importance (De Lange, 2004; Kusdinar, 2016) since problem-solving is a skill that can facilitate students in understanding mathematical concepts in a comprehensive, profound way, to be able to solve problems related to either material or everyday-life issues (Hudoyo and Sutawijaya, 1998; Marsound, 2005). The SSP that will be developed and produced in this study is based on character-filled heuristic strategies that are expected to increase student activities in problem-solving and be able to express character values in mathematics learning.

\section{Methodology}

\section{A. Research Methods and Subjects}

The present study used two different methods in terms of the spatial-temporal dimension. In the first stage, the mixed method was employed to obtain theoretical descriptions of problem-solving strategies and student character and experimentation in a learning treatment. While the second method which is the main objective of the next research is the Research and Development approach ( R \& D) by using the ADDIE model which consists of five phases: analysis phase, design phase, development and production stage, implementation phase, and evaluation phase. The analysis phase has been developed and will be followed by a schematization of the SSP scenario that will be developed in future research.

\section{B. Samples and Research Objects}

The sample of this study was teacher candidates of mathematics education in the IKIP PGRI Pontianak and Tanjungpura University Pontianak using a simple random sampling technique. Meanwhile, the object of research was the students' ability to solve problems based on heuristic strategy steps through identification, plan, do, and check and character values related to student learning independence. 


\section{Techniques, Tools and Data Analysis}

The data collection technique used in this study is direct measurement and communication. Then the collected data is checked according to the answer key and then the average percentage is calculated for each stage of the problemsolving ability test and two-way variance analysis test. The stages category refers to the criteria made by Morris and Gibbon (Purnamasari, 2015: 4) in Table I.

TABLE I

CRITERIA OF CATEGORIZATION

\begin{tabular}{cc}
\hline Percentage & Criteria \\
\hline$t>75 \%$ & High \\
$50 \%<t \leq 75 \%$ & Middle \\
$25 \%<t \leq 50 \%$ & Low \\
$t \leq 25 \%$ & Very Low (Pass/Fail) \\
\hline
\end{tabular}

Note: $t=$ Average of percentage for each phase

After the analysis of the quantitative data, qualitative data from the transcripts of interviews with the sample on the level of mathematical problem-solving abilities were analyzed. The analysis of these qualitative data used the stages of data reduction, data presentation, concluding, or verification.

\section{RESULTS AND DISCUSSION}

In Fig. 1 it can be seen that students have not been accustomed to doing problem-solving activities.

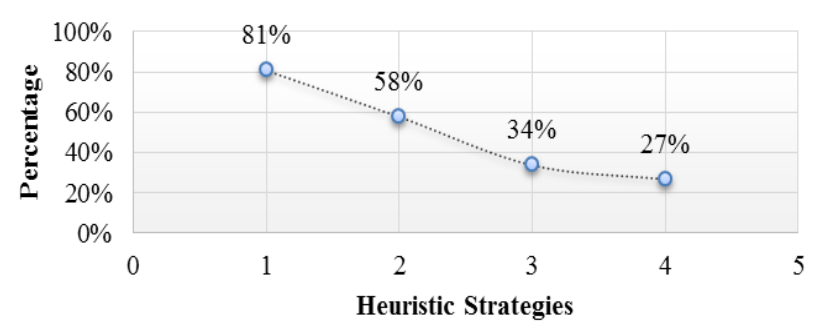

Fig. 1 Steps of Problem Solving Ability

Description: $\quad 1=$ Understanding the Problem

2 = Planning the Settlement

3 = Implement Planning

4 = Re-check

It is known from the steps of problem-solving ability above that the students' ability to understand the problem is in line with the high-category expectations, but the problemsolving ability is in the medium category. On the other hand, the students' ability to carry out planning and re-checking is far from expectation for it is in a low category. Fig. 2 shows the qualification of the students' problem-solving ability.

From the results of the students' problem-solving ability test it was found that none of them were in the category of high problem-solving abilities, but there were $14.71 \%$ of students had problem-solving abilities in the medium category. The remaining $70.59 \%$ and $14.71 \%$ had low and very low problem-solving abilities respectively.

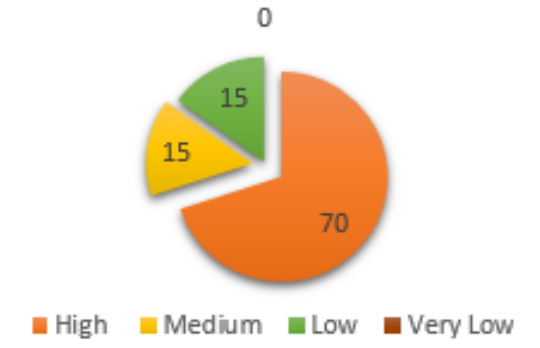

Fig. 2 Classification of Problem Solving Ability

These findings conclude that students' problem-solving abilities are in a low category since more than $50 \%$ of students obtain low grades. In addition to this finding, from the descriptions and interviews to selected students, it can be concluded that the influential factors to the level of problemsolving abilities are as follows: (1) students are less careful in understanding the problems in the provided test questions, consequently, they give an incorrect answer for the next stages of preparing a problem-solving plan, carrying out problem-solving, and re-checking back. However, they arranged the order of the stages sequentially; (2) students have not understood the given test questions well due to lack of training on non-routine questions; (3) students do not have ideas for solving problems; Consequently, students only write down what is known and what is being asked.

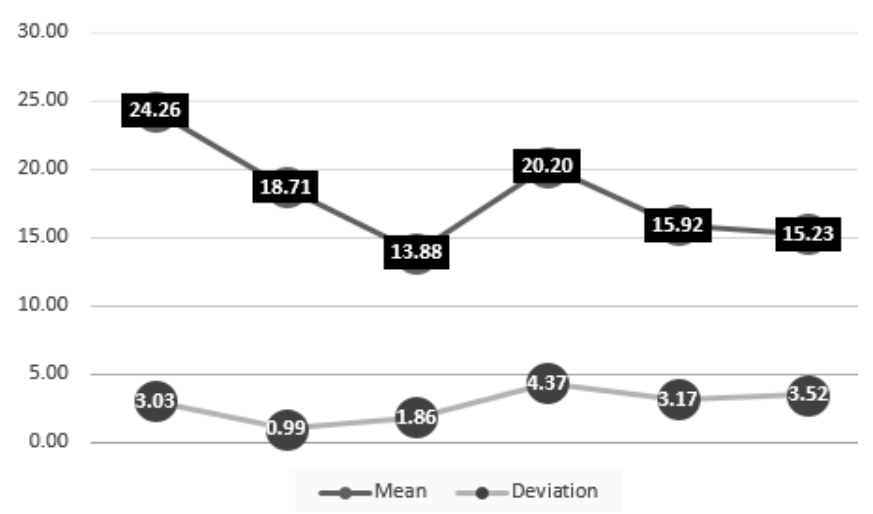

Fig. 3 Results of Problem Solving Ability

The findings of problem-solving ability results as in Fig. 3 for each of the high, medium, and low ability groups were given heuristic strategies got the average score (24.26; $18.17 ; 13.88)$, while those not given with heuristic strategies average scores are $(20.20 ; 15.92 ; 15.23)$. Then it was followed by two-way ANOVA calculations of unequal cells. It is obtained that $\mathrm{F}_{\mathrm{Obs}}=7.7401>\mathrm{F} \alpha=4.0012$. Following this, it was concluded that the students' with heuristic strategy learning obtain better problem-solving ability than those with the usual learning strategy. Meanwhile, the aspect of learning independence (character) has a significant influence on mathematical problem-solving ability (Darma and Firdaus, 2016).

Based on theoretical descriptions, problem-solving conceptions, and previous related studies, a schematization of development as in Fig. 4 and Table II as a model for integrating problem-solving with character values in the 
learning process through the facilitation of subject-specific pedagogic.

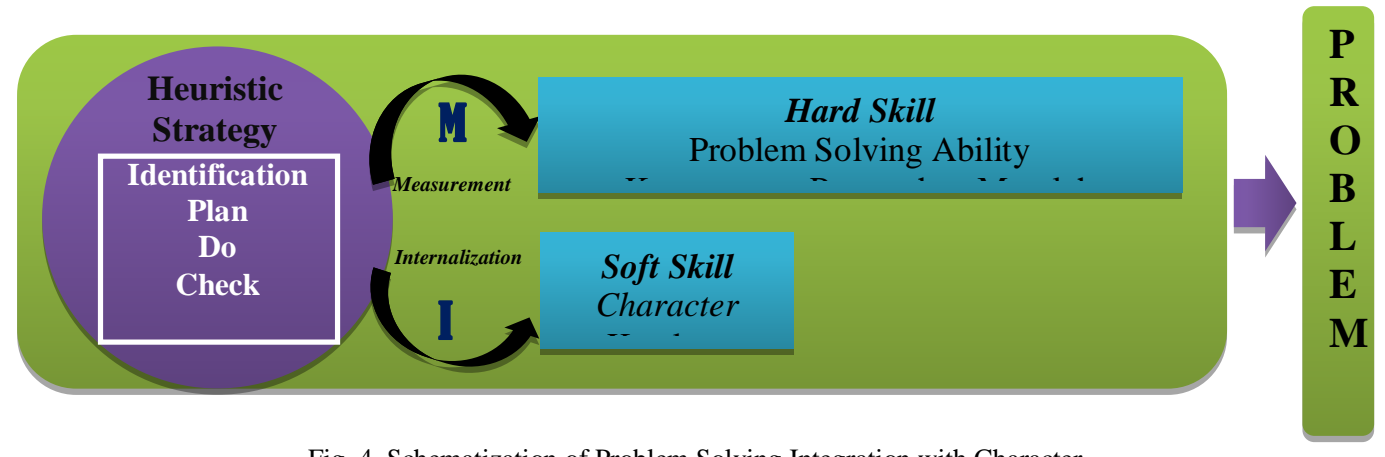

Fig. 4 Schematization of Problem Solving Integration with Character

TABLE II

INTERNALIZATION OF PROBLEM SOLVING IN CHARACTER DEVELOPMENT

\begin{tabular}{|c|c|c|}
\hline Heuristics & $\begin{array}{c}\text { Problem Solving } \\
\text { Activities }\end{array}$ & $\begin{array}{l}\text { Aspects of } \\
\text { Characters }\end{array}$ \\
\hline \multirow[t]{4}{*}{$\begin{array}{l}\text { Understanding } \\
\text { problems with } \\
\text { identifying and } \\
\text { classifying } \\
\text { problems }\end{array}$} & $\begin{array}{l}\text { aware of the } \\
\text { process and results } \\
\text { of thinking, in } \\
\text { understanding the } \\
\text { problem. }\end{array}$ & $\begin{array}{l}\text { Curiosity, self- } \\
\text { confidence, } \\
\text { discipline }\end{array}$ \\
\hline & $\begin{array}{l}\text { aware of the } \\
\text { process and results } \\
\text { of thinking, in } \\
\text { identifying } \\
\text { problems. }\end{array}$ & $\begin{array}{l}\text { Train self- } \\
\text { awareness (self- } \\
\text { reflection), } \\
\text { thoroughly }\end{array}$ \\
\hline & aware of the & Train self- \\
\hline & $\begin{array}{l}\text { process and results } \\
\text { of thinking, in } \\
\text { classifying } \\
\text { problems. }\end{array}$ & $\begin{array}{l}\text { awareness (self- } \\
\text { reflection), } \\
\text { thorough, } \\
\text { responsibility }\end{array}$ \\
\hline \multirow[t]{3}{*}{$\begin{array}{l}\text { Thinking about } \\
\text { action plans, } \\
\text { building } \\
\text { alternative } \\
\text { solutions }\end{array}$} & $\begin{array}{l}\text { aware of the } \\
\text { process and results } \\
\text { of thinking, in } \\
\text { developing } \\
\text { planning, }\end{array}$ & $\begin{array}{c}\text { Self-awareness, } \\
\text { independent, } \\
\text { creative }\end{array}$ \\
\hline & $\begin{array}{l}\text { Be aware of the } \\
\text { processes and } \\
\text { results of thinking, } \\
\text { in making plans. }\end{array}$ & $\begin{array}{c}\text { Self-awareness, } \\
\text { independent, } \\
\text { creative }\end{array}$ \\
\hline & $\begin{array}{l}\text { aware of the } \\
\text { process and the } \\
\text { results of his } \\
\text { thinking, in } \\
\text { formulating a plan. }\end{array}$ & $\begin{array}{c}\text { Self-awareness, } \\
\text { independent, } \\
\text { creative }\end{array}$ \\
\hline \multirow[t]{3}{*}{$\begin{array}{c}\text { Implement an } \\
\text { action plan by } \\
\text { choosing a } \\
\text { settlement strategy }\end{array}$} & $\begin{array}{l}\text { Resolve problems } \\
\text { according to } \\
\text { planning }\end{array}$ & $\begin{array}{l}\text { Responsibility, } \\
\text { working hard, } \\
\text { passionate, } \\
\text { consistent }\end{array}$ \\
\hline & $\begin{array}{l}\text { aware of the } \\
\text { process and results } \\
\text { of thinking in } \\
\text { monitoring the } \\
\text { implementation }\end{array}$ & $\begin{array}{l}\text { Self-awareness, } \\
\text { honesty, self- } \\
\text { introspection, } \\
\text { thoroughness, } \\
\text { discipline }\end{array}$ \\
\hline & $\begin{array}{l}\text { aware of the } \\
\text { process and the } \\
\text { results of his }\end{array}$ & $\begin{array}{c}\text { Self-awareness, } \\
\text { honesty, self- } \\
\text { introspection, }\end{array}$ \\
\hline
\end{tabular}

\begin{tabular}{|c|c|c|}
\hline Heuristics & $\begin{array}{c}\text { Problem Solving } \\
\text { Activities }\end{array}$ & $\begin{array}{l}\text { Aspects of } \\
\text { Characters }\end{array}$ \\
\hline & $\begin{array}{l}\text { thinking, in } \\
\text { completing the } \\
\text { action. }\end{array}$ & confidence \\
\hline \multirow[t]{2}{*}{$\begin{array}{l}\text { Evaluate \& re- } \\
\text { examine how the } \\
\text { best solution }\end{array}$} & $\begin{array}{l}\text { Share results with } \\
\text { colleagues in } \\
\text { evaluating actions. }\end{array}$ & $\begin{array}{l}\text { Working together, } \\
\text { respecting each } \\
\text { other, synergizing, } \\
\text { caring, friendly }\end{array}$ \\
\hline & $\begin{array}{c}\text { Evaluate the work } \\
\text { of friends and } \\
\text { yourself against } \\
\text { the appropriate } \\
\text { results. }\end{array}$ & $\begin{array}{l}\text { Responsible, } \\
\text { respect, tolerance, } \\
\text { honest, caring, } \\
\text { respect. }\end{array}$ \\
\hline
\end{tabular}

Furthermore, the quality of developed learning tools built on the character-contained heuristic strategy was assessed based on input from a team of experts or validators. The aspects of textbooks to assess were (1) the accuracy of the content coverage, including the suitability of the contents with the lecturing objectives, and the width or depth of the textbook contents, (2) the digestibility of textbooks, including systematic material presentation and an orderly and consistent format; (3) the use of language, namely the textbooks use clear, precise and communicative language and following students' levels; (4) interesting layout of the textbooks, and (5) the use of clear and precise illustrations. As a conclusion, the validators were asked to assess whether the SSP was valid or not. If at least four out of five validators state that the SSP is valid, the SSP is said to be of good quality.

In addition to assessing the quality of character-based heuristic learning devices, it also develops several instruments to assess profits by using these textbooks. To ensure and guarantee the quality of the subject-specific pedagogic being developed, the standard used to achieve a quality subject-specific pedagogic must be able to measure the achievement of valid, practical, and effective.

\section{CONCLUSIONS}

The learning process needs good planning, a response will be strong if the stimulus is also strong. Both planning and 
learning processes can produce a good achievement through a qualified evaluation of learning.

The heuristic strategy through the stages of identification, plan, do, and check is an alternative solution to learning mathematics that is very strong and potential in integrating characters as learning scenarios. This strategy can improve students' problem-solving ability and develop their character containing SSP.

The ideal SSP development will have the correct processimpact and expected results as the process of initiating future generations to be able and ready to compete and stand side by side in the era of the global community (learning to do and learning to live together) in an integrated manner in mathematics learning.

\section{ACKNOWLEDGMENT}

Thank you to KEMENRISTEKDIKTI as the provider of the Higher Education Cooperation Research grant in 2018 and the IKIP PGRI Pontianak as a proposer research team (TPP) and Tanjungpura University Pontianak as the partner research team (TPM) in the research activities.

\section{REFERENCES}

Bacher, J.M. (1991). Subject Specific Pedagogy: Are we ready to change our vision of teaching. Pennsylvania: Edinboro University of Pennsylvania.

Boonen, A. J. H., van Der Schoot, M., van Wesel, F., de Vries, M. H., \& Jolles, J. (2013). What underlies successful word problem solving? A path analysis in sixth grade students. Contemporary Educational Psychology, 38(3), 271-279.

Chavez, J.A. (2007). Enlivening problems with heuristics through learning activities and problem solving. Learning Science and Mathematics, 2, 1-8.

Corte, E. de, Greer, B., \& Verschaffel, L. (1996). Psychology of Mathematics Teaching and Learning, in D.C Berliner \& R.C. Calfee (Eds.), Hand Book of Educational Psychology, 491-549.

Darma, Y., \& Firdaus, M. (2016). Mengembangkan Kemampuan Pemecahan Masalah Melalui Pembelajaran Strategi Heuristik Dengan Pendekatan Metakognitif Ditinjau Dari Kemandirian Belajar Mahasiswa Calon Guru Matematika. JIPM (Jurnal Ilmiah Pendidikan Matematika), 5(1), 1-10.

De Lange, J. (2004). Mathematical Literacy for Living from OECD-PISA Perspective. Paris: OECD-PISA.

Ginsburg, H. P., Labrecque, R., Carpenter, K., \& Pagar, D. (2015). New possibilities for early mathematics education: Cognitive guidelines for designing highquality software to promote young children's meaningful mathematics learning. In R. Cohen Kadosh \& A. Dowker (Eds.), The Oxford Handbook Of Numerical Cognition, 1055-1098.
Hoon, T.S., Singh, P., Han, C.T., Kee, K.L. (2013). Heuristic approach experience in solving mathematical problems. Educational Research, 4(8), 607-611.

Hudoyo dan Sutawijaya. (1998). Pendidikan Matematika I. Jakarta: Dirjen Dikti Depdiknas.

Kemdiknas. (2010). Pengembangan Pendidikan Budaya dan Karakter Bangsa. Jakarta: Puskur-Balitbang.

Kilpatrick, J.,Swafford, J.,\& Findell, B. (2001). Adding It Up: Helping Children Learn Mathematics. Washington DC: National Academy Press.

Koichu,B., Berman, A., And Moore, M. (2014). The effect of promoting heuristic literacy on the mathematical aptitude of middle-school students. International Journal of mathematical Education in Science and Technology. http://www.tandfonline.com/loi/tmes20

Kusdinar, U. (2016). Use Of Heuristic Strategies To Increase The Ability of Mathematical Problem Solving. Proceeding-The Progressive and Fun Education Seminar, 84-89. Surakarta: UMS.

Lester, F., Garofalo, J. \& Kroll, D. (1989). The Role of Metacognition in Mathematical Problem Solving: A Study of Two Grade Seven Classes (Final Report to The National Science Foundation, NSF Project No. MDR 85-50346). Blomington: Indiana University, Mathematics Education Development Center.

Marsound, D. (2005). Improving Math Education in Elementary School : A Short Book for Teachers. Oregon : University of Oregon. [online]. Tersedia http://darkwing.uoregon.edu/.../ElMath.pdf

Peraturan Pemerintah Nomor 19 Tahun 2005, tentang Standar Nasional Pendidikan. Jakarta: Depdiknas.

Purnamasari, Pawestri, D. (2015). Analisis Kmampuan Pemecahan Maalah Matematika Siswa Kelas XI SMK Muhammadiyah 1 Patuk Pada Pokok Bahasan Peluang. Yogyakarta: Jurnal UNY.

Reys, Robert E., Marilyn N. Suydam, Mary Montgomery Lindquist. (1998). Helping Children Learn Mathematic (5th ed). Needham Hwight : Allyn \& Bacon.

Rokhman, F., Hum, M., Syaifudin, A., Yuliati. (2014). Character Education For Golden Generation 2045 (National Character Building for Indonesian Golden Years). Procedia - Social and Behavioral Sciences, 141, 1161-1165.

Schoenfeld, A. (1992). Learning to Think Mathematically: Problem Solving. Metacognition, and sense Making in Mathematics. In D.A. grows (Ed.), Handbook of Research on Mathematics Teaching and Learning, 334-370.

Schoenfeld, Alan H. (1980). Heuristik in the Classroom, dalam Krulik, S. dan Reys, Robert, E. (Eds). Problem Solving in School Mathematic. Virginia: NCTM.

Sfard, A. (2012). Introduction: Developing mathematical discourse-some insights from communicational research. International Journal of Educational Research, 51-52, 1-9. 
Shadiq, F. (2009). Apa dan Mengapa Matematika Begitu Penting?. Yogyakarta: Departemen Pendidikan Nasional.

Suherman, E. (2001). Strategi Pembelajaran Matematika Kontemporer. Bandung: JICA.

Superfine, C., A. (2008). Planning for Mathematics Instructions: A Model of Experienced Teachers' Planning Processes in the Context of a Reform Mathematics Curriculum. The Mathematics Educator, 18(2), 11- 22.
Ülger, M., Yiğittir, S., Ercan, O. (2014). Secondary School Teachers' Beliefs On Character Education Competency. Procedia-Social and Behavioral Sciences, 131, $442-449$.

Verschaffel, L., De Corte, E., Lasure, S., Van Vaerenbergh, G., Bogaerts, H., \& Ratinck, E. (1999). Learning to solve mathematical application problems: A design experiment with fifth graders. Mathematical Thinking and Learning, 1, 195-229. 